\title{
Selenium species in diet containing carnosic acid, fish and rapeseed oils affect fatty acid profiles in lamb muscles
}

\author{
A.J. Rozbicka-Wieczorek ${ }^{1}$, M. Czauderna ${ }^{1,3}$, E. Więsyk ${ }^{1}$ and A. Radzik-Rant ${ }^{2}$ \\ ${ }^{1}$ The Kielanowski Institute of Animal Physiology and Nutrition, Polish Academy of Sciences \\ Instytucka 3, 05-110 Jabłonna, Poland \\ ${ }^{2}$ Warsaw University of Animal Sciences - SGGW, Department of Animal Breeding \\ Ciszewskiego 8, 02-786 Warsaw, Poland
}

KEY WORDS: lambs, selenized yeast, selenate, rapeseed oil, fish oil, carnosic acid, fatty acids, muscles

Received: 3 November 2015

Revised: $\quad 16$ May 2016

Accepted: 26 August 2016

${ }^{3}$ Corresponding author:

e-mail: m.czauderna@ifzz.pl

\begin{abstract}
The aim of the study was to evaluate the effects of highly selenized yeast $(\mathrm{SeY})$ or selenate (SeVI) on fatty acids (FA) profiles in musculus longissimus dorsi (MLD) and musculus biceps femoris (MBF) of male lambs. Lambs, divided into 3 groups of 6 animals each, were individually penned and fed for 35 days control diet containing $2 \%$ rapeseed oil (RO), $1 \%$ fish oil (FO) and $0.1 \%$ carnosic acid (CA) or experimental diets with additional $0.35 \mathrm{mg}$ Se as $\mathrm{SeY}$ (the organic Se-form) or SeVI (the inorganic Se-form) per kg of the control diet. In lambs fed SeVI diet body weight gain after 21 and 35 days of feeding was increased; whereas in lambs fed SeY diet increased concentrations of C14:0, C16:0, C18:0, and the sums of atherogenic saturated fatty acids (SFA), thrombogenics SFA and all FA in MLD and MBF were noted. The content of t11C18:1 in MLD and MBF was higher in lambs fed SeY and SeVI diets but the concentration of sum of $n-3$ long-chain polyunsaturated FA in MLD was decreased in comparison to the control group. The sum of conjugated linoleic acid isomers ( $\Sigma C L A)$ content in MLD was higher in SeY group in comparison to the control group. In both examined groups $\Sigma$ CLA content in MBF was higher in comparison to the control group. In conclusion, the addition of inorganic or organic Se-chemical form into lambs' feed based on RO, FO and CA differently modifies body weight gains as well as FA profile in examined muscles.
\end{abstract}

\section{Introduction}

Lipid metabolism in the rumen significantly influences compositions of fatty acids (FA) in ruminant tissues (Demirel et al., 2004). A small part of dietary FA is catabolised to volatile FA (VFA) or to $\mathrm{CO}_{2}$ (Buccioni et al., 2012). Ruminal microbes are able to synthesize FA de novo and to biohydrogenate free unsaturated FA (UFA) into corresponding saturated configurations. Dietary lipids can be largely hydrolysed by enzymes of ruminal microbes (Buccioni et al., 2012). Ruminal lipolysis results in release of free FA from lipids to allow biohydrogenation of free UFA into intermediates (e.g., cis 9 trans 11C18:2, trans $11 \mathrm{C} 18: 1$ or trans 10C18:1) or finally into C18:0. Thus, ruminant meat is considered to be less healthy due to its relatively low contents of polyunsaturated FA (PUFA) and high concentrations of saturated FA (SFA) which stand behind several diseases such as obesity, cancer or 
cardiovascular problems (Buccioni et al., 2012). Although changing FAs profiles is less possible in ruminants than in pigs, there are still numerous studies on dietary manipulation of the FA composition through various feeding strategies. Amounts and type of fat and pro- or antioxidants added to the diet can influence the UFA biohydrogenation in the rumen and FA profiles in ruminant tissues (Niedźwiedzka et al., 2008; Buccioni et al., 2012; Czauderna et al., 2012a,b, 2015; Kišidayová et al., 2014); these studies showed that feeding rapeseed oil (RO), linseed oil (LO) and especially fish oil (FO) rich in $n$-3PUFA decreased SFA content in tissues and increased contents of valuable monounsaturated FA (MUFA) and PUFA. Our studies (Wąsowska et al., 2006; Czauderna et al., 2012a) showed that RO, LO and especially FO are able to modify the biohydrogenation by decreasing the enzymatic isomerization capacity of linoleic (LA) or $\alpha$-linolenic ( $\alpha$ LNA) acids. Thus, these oils elevate a trans 11C18:1 (t11C18:1) content in ruminant tissues; dietary RO increased contents of conjugated linoleic acid isomers in ruminal fluid and tissues (Buccioni et al., 2012; Czauderna et al., 2015). FO, rich in long-chain PUFA (LPUFA), inhibited the growth and activity of ruminal microorganisms (e.g., bacterial isomerase activity). PUFA, especially LPUFA toxically affecting cellulolytic bacteria and protozoa act against ruminal lactate producers thereby favouring propionate producers (Wąsowska et al., 2006; Buccioni et al., 2012). Consequently, the percentage of undesirable SFA in ruminant tissues decrease, while the percentage of UFA, particularly n-3LPUFA, in tissues increase (Buccioni et al., 2012).

The balance between UFA (especially LPUFA and n-6PUFA) and pro- or antioxidants (like Secompounds) in feed is the critical factor influencing the quality of farm animals' meat (Traulsen et al., 2004; Niedźwiedzka et al., 2008; Czauderna et al., 2009, 2012a; Thiry et al., 2012; RozbickaWieczorek et al., 2014). Essential physiological roles of half of the Se-proteins are to maintain the appropriate metabolism of arachidonic acid (AA) and low levels of free-radicals within cells, so, reducing oxidative stress and peroxidative damage of lipids (Traulsen et al., 2004). Recent studies showed that diets with organic Se-compounds, like highly selenized yeast $(\mathrm{SeY})$, or inorganic Se-compounds, like selenate ( $\mathrm{SeVI})$, change FA contents in animal tissues (Juniper et al., 2008; Czauderna et al., 2009, 2012a; Krajewska et al., 2012; Ohgushi-Imamura et al., 2014; Rozbicka-Wieczorek et al., 2014, 2016). Moreover, carnosic acid (CA) can protect UFA in tissues from peroxidation damage (HernándezHernández et al., 2009; Jordan et al., 2013). CA is a natural diterpene with antioxidant properties found in rosemary (Rosmarinus officinalis) and common sage (Salvia officinalis). CA can modify gut microbiota, resulting in changes of the bacterial metabolism in the rumen (Morán et al., 2012, 2013; Jordan et al., 2013).

Thus, we hypothesized that SeVI or SeY added to a diet with CA, FO (rich in LPUFA) and RO (rich in proinflammatory $n$-6PUFA), would modify FA profiles in muscles. We expected that these modifications would be depended on the chemical forms of dietary Se. So, the aim of the present study was to examine the effects of SeY or SeVI added to a diet with CA, FO and RO on FA profiles, especially LPUFA and n-6PUFA, in musculus longissimus dorsi (MLD) and musculus biceps femoris (MBF) of lambs.

\section{Material and methods}

\section{Animals, diets and experimental design}

The study was conducted under the authority of the Third Local Commission of Animal Experiment Ethics at the Warsaw University of Life Sciences - SGGW (Warsaw, Poland).

Eighteen male Corriedale lambs with an average body weight (BW) of $30.4 \pm 2.6 \mathrm{~kg}$ at the beginning of the study were individually penned and divided into 3 groups of 6 lambs each. During a 3-week preliminary period the lambs had free access to basal

Table 1. Composition of basal diet

\begin{tabular}{|c|c|c|c|c|c|}
\hline \multirow[b]{2}{*}{ Indices } & \multirow{2}{*}{$\begin{array}{l}\text { Meadow } \\
\text { hay }\end{array}$} & \multicolumn{3}{|c|}{ Concentrate } & \multirow{2}{*}{$\begin{array}{l}\text { Vitamin } \\
\text { mineral } \\
\text { premix }\end{array}$} \\
\hline & & $\begin{array}{l}\text { barley } \\
\text { meal }\end{array}$ & $\begin{array}{l}\text { soyabean } \\
\text { meal }\end{array}$ & $\begin{array}{l}\text { wheat } \\
\text { starch }\end{array}$ & \\
\hline Ingredient, $\mathrm{g} \cdot \mathrm{kg}^{-1}$ & 360 & 165 & 360 & 90 & 20 \\
\hline \multicolumn{6}{|l|}{$\ln \mathrm{DM}, \%$} \\
\hline crude protein & 9.50 & 9.94 & 41.81 & 0.90 & \\
\hline crude fibre & 27.29 & 2.87 & 4.34 & - & \\
\hline crude fat & 3.40 & 2.50 & 2.25 & 0.09 & \\
\hline ash & 4.85 & 1.84 & 6.16 & 0.12 & \\
\hline neutral detergent fibre & 52.17 & 18.02 & 18.81 & - & \\
\hline acid detergent fibre & 32.08 & 4.61 & 6.44 & - & \\
\hline acid detergent lignin & 4.47 & 1.14 & 1.49 & - & \\
\hline \multicolumn{6}{|l|}{ Gros energy, } \\
\hline MJ per kg of DM & 17.1 & 16.3 & 17.8 & 16.7 & \\
\hline
\end{tabular}

1 POLFAMIX OK (Grodzisk Mazowiecki, Poland), supplied per kg of diet: g: Ca 285, P 16, Na 56, Fe as sulphate 1, Cu as sulphate 0.5, $\mathrm{Mn}$ as sulphate $5.8, \mathrm{Zn}$ as sulphate 7.5 ; $\mathrm{mg}$ : $\mathrm{Co}$ as carbonate 42 , I as iodate 10, Se as selenite 6; and IU: vit. A 500000 , vit. $D_{3} 125000$, vit. E as a-tocopherol 25000 
Table 2. Experimental scheme and composition of control and experimental diets including $\mathrm{SeY}^{1}$ or $\mathrm{SeV}^{2}$ and body weight of lambs

\begin{tabular}{|c|c|c|c|c|c|c|}
\hline \multirow{2}{*}{ Diet } & \multirow{2}{*}{ Diet composition ${ }^{3}$} & \multicolumn{3}{|c|}{ Body weight $(\mathrm{BW})^{4}, \mathrm{~kg}$} & \multicolumn{2}{|c|}{ Body weight gain (BWG) $)^{5}, \%$} \\
\hline & & $\mathrm{BW}_{\text {initial }}$ & $\mathrm{BW}_{21 \text { days }}$ & $\mathrm{BW}_{35 \text { days }}$ & $\mathrm{BWG}_{21 \text { days }}$ & $\mathrm{BWG}_{35 \text { days }}$ \\
\hline Control & $2 \% \mathrm{RO}, 1 \% \mathrm{FO}$ and $0.1 \% \mathrm{CA}$ & 30.6 & 32.1 & 37.2 & 4.8 & 21.5 \\
\hline $\mathrm{SeY}$ & $\begin{array}{l}\text { control diet }+0.35 \mathrm{mg} \text { of Se as SeY in } 1 \mathrm{~kg} \\
\text { of control diet }\end{array}$ & 30.3 & 33.4 & 36.8 & $10.5^{* *}$ & 21.6 \\
\hline SeVI & $\begin{array}{l}\text { control diet }+0.35 \mathrm{mg} \text { of Se as SeVI in } 1 \mathrm{~kg} \\
\text { of control diet }\end{array}$ & 30.3 & 34.2 & 38.5 & $12.9^{* *}$ & $26.8^{* \#}$ \\
\hline
\end{tabular}

${ }^{1}$ SeY - selenized yeast (Se-Saccharomyces cerevisiae; Sel-Plex, Alltech In., Nicholasville, KY, USA); ${ }^{2}$ SeVI - sodium selenate (VI); ${ }^{3} \mathrm{RO}$ - rapeseed oil, FO - fish oil, CA - carnosicacid; Se content: $\mathrm{mg} \cdot \mathrm{kg}^{-1}$ : in control diet 0.16; in SeY and SeVIdiets - 0.51 (Ruszczyńskaetal., 2016); ${ }^{4}$ the average $\mathrm{BW}$ after 3-week preliminary period ( $\left.\mathrm{BW}_{\text {initial }}\right)$ and after 21 and 35 days of experimental period $\left(\mathrm{BW}_{21 \text { days }}\right.$ and $\mathrm{BW}_{35 \text { days }}$, respectively); ${ }^{5}$ relative body weight gain $\left(\mathrm{BWG}_{21 \text { days, }}, \mathrm{BWG}_{35 \text { days }}\right)$ after 21 and 35 days of experimental period; $B W G, \%=\left[\left(\mathrm{BW}_{21 \text { or } 35 \text { days }}-\mathrm{BW}_{\text {initial }}\right) \times 100 \%\right] / \mathrm{BW}_{\text {initial' }}$; mean values in column (for each muscle separately) with ".* are significantly different from control group at $P<0.05$ or $P<0.01$, respectively, and \#,\# - from SeY group at $P<0.05$ or $P<0.01$, respectively

diet (the standard concentrate-hay diet with vitamin and mineral premix; Table 1) and ad libitum access to water. Main fatty acids in concentrate were: $\mathrm{mg} \cdot \mathrm{kg}^{-1}$ : C14:0 104, C16:0 3189, C18:0 1425, c9C18:1 774, LA 29163, $\alpha$ LNA 1014. It was enriched in $2 \%$ rapeseed oil (RO) and $1 \%$ odourless fish oil (FO; iodine value $50-65 \mathrm{~g} \cdot 100 \mathrm{~g}^{-1} \mathrm{FO}$; acid value $20 \mathrm{mg}$ $\mathrm{KOH} \cdot \mathrm{g}^{-1} \mathrm{FO}$; Table 2). After the preliminary period, for 35 days the lambs were fed BD with $2 \% \mathrm{RO}, 1 \% \mathrm{FO}$ and $0.1 \% \mathrm{CA}$ (i.e. control diet) and two experimental diets (Table 2). To experimental diets was added $0.35 \mathrm{mg}$ of Se as highly selenized yeast $(\mathrm{SeY})$ or sodium selenate $(\mathrm{SeVI})$ to $1 \mathrm{~kg}$ of the control diet. The SeY (Se-Saccharomyces cerevisiae) was donated by Sel-Plex (Alltech In., Nicholasville, KY, USA). About $83 \%$ of the total $\mathrm{Se}$ content of $\mathrm{SeY}$ represented $\mathrm{Se}$ in the form of Se-methionine (Se-Met) incorporated into the proteins of Saccharomyces cerevisiae (Czauderna et al., 2009); the chemical composition of SeY was presented in the previous publication (Czauderna et al., 2009). SeVI was provided by Sigma-Aldrich (St. Louis, MO, USA).

All diets were formulated to be isoenergetic and isonitrogenous. All diets were adjusted weekly and supplied as two equal meals at 7:30 and 16:00 each day to ensure free access to feed. Fresh drinking water was always available. The diet allowance was changed weekly according to BW of lambs. All lambs were fed the same portion of freshly prepared control and experimental diets. The average daily diet intake was $1.08 \mathrm{~kg}$ per lamb. Body weight (BW) and relative body weight gain (BWG) of lambs were measured after 21 and 35 days of the experimental period (Table 2). During the preliminary and experimental period, all lambs were under professional veterinary observation by the veterinar- ian authorized by the Third Local Commission of Animal Experiment Ethics at the Warsaw University of Life Sciences-SGGW (Warsaw, Poland). After 35 days the lambs were euthanized by the intramuscular injection of xylazine $\left(2-4 \mathrm{mg} \cdot 10 \mathrm{~kg}^{-1} \mathrm{BW}\right)$ at 7:00 - 8:00 after $12 \mathrm{~h}$ of starvation. The colour, consistency as well as fatty acid and/or amino acid profiles were analysed in all internal organs and adipose tissues. The $M L D$ and $M B F$ muscles were homogenized and then frozen; muscle samples were stored in sealed tubes at $-32{ }^{\circ} \mathrm{C}$ until analysis.

\section{Chemicals}

Acetonitrile and n-hexane (99\%) were purchased from Lab-Scan (Dublin, Ireland). A conjugated linoleic acid (CLA) isomer mixture and other FA standards and $25 \% \mathrm{BF}_{3}$ in methanol were provided by Sigma-Aldrich (St. Louis, MO, USA). Chloroform, dichloromethane, methanol, $\mathrm{KOH}$, $\mathrm{NaOH}, \mathrm{Na}_{2} \mathrm{SO}_{4}$ and conc. $\mathrm{HCl}$ were purchased from POCh (Gliwice, Poland). All other chemicals were of analytical grade and organic solvents were of HPLC grade. CA was purchased from Hunan Geneham Biomedical Technology Ltd. (Changsha, Hunan, China). RO and odourless FO were supplied by AGROSOL Company (Pacanów, Poland). RO comprised the following main FA: $\mathrm{mg} \cdot \mathrm{kg}^{-1} \mathrm{RO}$ : C14:0 56, C16:0 13091, c9C16:1 33, C18:0 5490, c9C18:1 385859, c12C18:1 786, LA 282394, aLNA 38474, C20:0 194, c11C20:1 108, C22:0 430 and $c 15 \mathrm{C} 24: 161$. FO included the following main FA: $\mathrm{mg} \cdot \mathrm{kg}^{-1}$ FO: C12:0 82, C14:0 12345, c9C14:1 215, C15:0 477, C16:0 56947, c7C16:1 318, c9C16:1 420, $\Sigma C 16: 215586, \mathrm{C} 17: 0493$, , $9 \mathrm{C} 17: 1$ 193,C18:0 9452, c6C18:1 188, c7C18:1 842, c9C18:1 290592, c12C18:1 15834, c14C18:1 159, LA 114512, aLNA 20968, c11C20:1 24206, c7c9c12c15C18:4 473, 
c11c14C20:2 2270, c8c11c14C20: 3 258, AA 304, c8c11c14c17C20:4 607, C22:0 139, c13C22:1 11036, c11C22:1 1704,C20:5n-3(EPA) 6792, c13c16C22:295, c7c10c13c16C22:4 144, c15C24:1 397, C22:5n-3 (DPA) 1560 and DHA 26570. The meadow hay contained the following main FA: $\mathrm{mg} \cdot \mathrm{kg}^{-1}$ : $\mathrm{C} 8: 083$, C12:0 142, C14:0 239, c9C15:1 131, C16:0 4034, c9C16:1 184, C18:0 459, c9C18:1 1266, c12C18:1 72, LA 13100, aLNA 4178, C20:0 58, c11C20:1 74, C22:0 101, C24:0 69, c15C24:1 71.

Water used for the preparation of mobile phases and chemical reagents was prepared using an Elix ${ }^{\mathrm{TM}}$ water purification system (Millipore, Billerica, MA, USA). The mobile phases were filtered through a $0.45 \mu \mathrm{m}$ membrane filter (Millipore, Billerica, MA, USA) and then degassed for $2-3 \mathrm{~min}$ in a vacuum with ultrasonication prior to use.

\section{Analytical methods and chromatographic equipment}

FA, including CLA isomers, in all muscle samples were saponified according to Rozbicka-Wieczorek et al. (2014) followed by gentle methylations. The base- and acid-catalysed methylations were introduced for preparation of FA methyl esters (FAME) in processed muscle samples (RozbickaWieczorek et al., 2014). FAME were then quantified using gas chromatography according to Rozbicka-Wieczorek et al. (2014). The analyses of all FAME were performed on a gas-chromatograph (GC-MS-QP2010 Plus-EI; SHIMADZU, Tokyo, Japan) equipped with a BPX70-fused silica capillary column $(120 \mathrm{~m} \times 0.25 \mathrm{~mm}$ i.d. $\times 0.25 \mu \mathrm{m}$ film thickness; Phenomenex, Torrance, CA, USA) and a quadrupole mass selective detector (Model 5973N; SHIMADZU, Tokyo, Japan).

Methylated CLA isomers in muscle samples were determined accordingly to the method of Czauderna et al. (2009) by using a 625 LC system that included a controller for gradient elution and two pumps (Model 515), a 712 WISP-autosampler and a 996-PAD photodiode array detector (Waters, Milford, MA, USA). This 625 LC system was equipped with two ion-exchange columns loaded with silver-ions $(250 \times 4.6 \mathrm{~mm}$ ChrompackChromSper $5 \mu \mathrm{m}$ Lipids; Elmer, NJ, USA). The CLA isomers in $M L D$ and $M B F$ samples were determined using the isocratic elution programme (low-rate of $1.5 \mathrm{ml} \cdot \mathrm{min}^{-1}$ ) and UV detection at $234 \mathrm{~nm}$ (column temperature $23{ }^{\circ} \mathrm{C}$ ). The eluent was prepared from n-hexane and acetonitrile $(99.9: 0.1 \mathrm{v} / \mathrm{v})$. All positional and geometric CLA isomers in muscles were satisfactorily separated from all endogenous species present in $M L D$ and $M B F$ in about $65 \mathrm{~min}$ (Czauderna et al., 2012a).

\section{Statistical analyses}

Statistical analyses were performed using the STATISTICA ver. 10 PL software package (StatSoft Inc.; Tulsa, OK, USA). The statistical analysis of the effects of dietary additives (SeY or SeVI) on concentration of selected FA in muscles (MLD and $M B F$ ) was conducted using the non-parametric Mann-Whitney $U$ test and it was carried out between: control and SeY group, control and SeVI group and $\mathrm{SeY}$ and $\mathrm{SeVI}$ group. The obtained results are presented as mean value with standard error of mean (SEM).

\section{Results}

No harmful symptoms (e.g., diarrhoea or vomiting) in lambs fed diets containing RO, FO and CA were observed. Moreover, no visual pathological changes, acute selenium toxicity and toxic changes of dietary SeY or SeVI were reported by McDowell et al. (2005) in the liver, kidneys, spleen, pancreas, muscles, adipose tissues and bones of lambs compared to the control ones. No non-physiological changes in FA and AA concentrations were found in the internal organs and adipose tissues of lambs fed $\mathrm{SeY}$ or SeVI diets (data not presented).

Lamb BWG after 21 days $\left(\mathrm{BWG}_{21 \text { days }}\right)$ was increased in both experimental groups ( $\mathrm{SeY}$ and $\mathrm{SeVI}$ ) in comparison to the control group (Table 2). In contrast, after 35 days the BWG was increased only in SeVI group in comparison to both control and $\mathrm{SeY}$ group.

\section{Effects of SeY or SeVI on the profiles of SFA and MUFA in muscles}

In lambs fed the SeY diet the concentrations of C14:0, C16:0 and C18:0 FA and the sums of atherogenic SFA $\left(\mathrm{A}^{\mathrm{SFA}}\right)$, thrombogenic SFA $\left(\mathrm{T}^{\mathrm{SFA}}\right)$ and all assayed FA in $M L D$ and $M B F$ were increased $(P<0.05)$ in comparison to control and SeVI groups (Table 3). In this group also the atherogenic index $\left({ }_{\text {index }} \mathrm{A}^{\mathrm{SFA}}\right)$ and $\mathrm{A}^{\mathrm{SFA}}$ : FA ratio were increased in comparison to both other groups and thrombogenic index $\left({ }_{\text {index }} \mathrm{T}^{\mathrm{SFA}}\right)$ and $\mathrm{T}^{\mathrm{SFA}}$ : FA ratio only in comparison to the control group. In $M B F$ sum of SFA was increased after SeY addition into diet in comparison to both control and SeVI diets. In the SeVI group only index $\mathrm{T}^{\mathrm{SFA}}$ and $\mathrm{T}^{\mathrm{SFA}}$ : FA ratio were increased in comparison to the control group in $M L D$. In $M B F$ the addition of SeVI 
Table 3. Concentrations $\left(\mathrm{g} \cdot \mathrm{kg}^{-1}\right)$ of $\mathrm{C} 14: 0, \mathrm{C} 16: 0, \mathrm{C} 18: 0, \mathrm{SFA}^{1}$, sum of all assayed fatty acids (FA), atherogenic SFA $\left(\mathrm{A}^{\mathrm{SFA}}\right)^{2}$ and thrombogenic SFA $\left(T^{S F A}\right)^{3}$, and values of atherogenic index $\left({ }_{\text {index }} A^{\text {SFA }}\right)^{4}$, thrombogenic index $\left({ }_{\text {index }}{ }^{\text {SFA }}\right)^{5}, A^{\text {SFA }}$ : FA, $T^{\text {SFA }}$ : FA and SFA : FA ratios in musculus longissimus dorsi (MLD) and musculus biceps fermoris (MBF) of lambs fed control and experimental diets

\begin{tabular}{|c|c|c|c|c|c|c|c|c|c|c|c|c|}
\hline Group $^{6}$ & C14:0 & C16:0 & C18:0 & $A^{\text {SFA }}$ & $T^{S F A}$ & SFA & FA & index $A^{\text {SFA }}$ & index ${ }^{\text {SFA }}$ & $A^{\text {SFA }}: F A$ & $\mathrm{~T}^{\mathrm{SFA}}: \mathrm{FA}$ & SFA : FA \\
\hline \multicolumn{13}{|l|}{$M L D$} \\
\hline control & 0.218 & 2.35 & 1.77 & 2.60 & 4.34 & 4.53 & 9.9 & 0.602 & 0.959 & 0.260 & 0.433 & 0.455 \\
\hline $\mathrm{SeY}$ & $0.442^{*}$ & $3.54^{*}$ & $2.62^{*}$ & $4.02^{*}$ & $6.60^{*}$ & 6.89 & $14.3^{*}$ & $0.685^{*}$ & $1.191^{*}$ & 0.273 & $0.453^{*}$ & 0.476 \\
\hline SeVI & $0.183^{\#}$ & $2.14^{\#}$ & $1.90^{\#}$ & $2.35^{\#}$ & $4.22^{\#}$ & 4.40 & $9.3^{\#}$ & $0.584^{\#}$ & $1.156^{*}$ & $0.251^{\#}$ & $0.455^{*}$ & 0.476 \\
\hline SEM & 0.086 & 0.04 & 0.19 & 0.29 & 0.37 & 0.53 & 0.8 & 0.017 & 0.031 & 0.003 & 0.003 & 0.004 \\
\hline \multicolumn{13}{|l|}{$M B F$} \\
\hline control & 0.180 & 1.88 & 1.40 & 2.08 & 3.46 & 3.58 & 7.2 & 0.716 & 1.167 & 0.287 & 0.479 & 0.497 \\
\hline $\mathrm{SeY}$ & $0.320^{*}$ & $2.81^{*}$ & $1.97^{*}$ & $3.16^{*}$ & $5.10^{*}$ & $5.29^{*}$ & $11.0^{*}$ & 0.719 & 1.226 & 0.288 & 0.467 & 0.484 \\
\hline SeVI & $0.141^{\#}$ & $1.76^{\#}$ & $1.41^{\#}$ & $1.91^{\#}$ & $3.31^{\#}$ & $3.42^{\#}$ & 7.1\# & $0.617^{* \#}$ & $1.116^{\#}$ & $0.263^{\#}$ & 0.464 & 0.480 \\
\hline SEM & 0.020 & 0.14 & 0.10 & 0.12 & 0.20 & 0.21 & 0.4 & 0.012 & 0.021 & 0.003 & 0.003 & 0.003 \\
\hline
\end{tabular}

to diets caused lower value of ${ }_{\text {index }} \mathrm{A}^{\mathrm{SFA}}$ in comparison to control group and lower values of ${ }_{\text {index }} T^{\mathrm{SFA}}$ and $\mathrm{A}^{\mathrm{SFA}}$ : FA ratio in comparison to $\mathrm{SeY}$ group.

In lambs fed both SeY and SeVI diets t11C18:1 content in $M L D$ and $M B F$ was higher in comparison to the control group; however in SeY group this increase was more pronounced. In both $M L D$ and $M B F$ the concentrations of $c 9 \mathrm{C} 18: 1$ and MUFA as well as value of $\Delta 9$-desaturase index $\left(\Delta 9_{\text {index }}\right)$ was higher in SeY group in comparison to control and SeVI groups. On the other hand, the addition of SeVI to diet decreased $(P<0.05) \Delta 9_{\text {index }}$ in $M B F$ when compared to both control and SeY diets.

\section{Effects of SeY or SeVI on the PUFA profile in muscles}

The current study has demonstrated that feeding lambs with SeY and SeVI diets decreased $(P<0.05)$ the concentration sum of n-3 long-chain PUFA ( $n$-3L) in $M L D$ when compared to the control diet (Table 5) because the decreased concentration of docosahexaenoic acid (c4c7c10c13c16c19C22:6, DHA) and no change in docosapentaenoic acid (c7c10c13c16c19C22:5, DPA) content were observed in both groups (Table 4). No such effect was observed in $M B F$. In contrast to $M D L$, in $M B F$ the SeY diet caused higher concentration $(P<0.05)$ of PUFA, including $n$-6PUFA (n-6), LA, $\alpha$-linolenic acid ( $\alpha$ LNA) and LPUFA, in comparison to the control diet but not SeVI diet (Tables 4 and 5). The arachidonic acid content was increased in both exam- ined groups but also only in $M B F$. The addition of SeVI to the diet increased n- $6: n-3$ ratio as compared to the control diet (in $M L D$ and $M B F$ ) and SeY (only in $M L D)$. The addition of SeVI to diet increased $(P<0.05)$ the concentration ratios of PUFA : SFA, PUFA : FA, LPUFA : FA and n-3L : SFA in $M L D$ and $M B F$ as compared to the SeY diet. Feeding lambs $\mathrm{SeY}$ and SeVI diets decreased the $\Delta 4$-desaturase index $\left(\triangle 4_{\text {index }}\right)$ in $M L D$ and $M B F$ in comparison to the control group. The $\Delta 5$-desaturase index $\left(\Delta 5_{\text {index }}\right)$ was increased in both groups but only in $M L D$. No difference in elongase index $\left(\mathrm{El}_{\text {index }}\right)$ was observed among all groups in both muscles. Feeding SeY diet caused lower PUFA : SFA, PUFA : FA, LPUFA : FA, n-3L : SFA ratios in $M L D$ in comparison to control and SeVI groups, and n-3L : FA ratio in comparison to the control group. In contrast in $M B F$, the addition of SeVI to diet increased PUFA : SFA and LPUFA : FA ratios in comparison to control and $\mathrm{SeY}$ groups, and PUFA : FA ratio in comparison to $\mathrm{SeY}$ group.

The $t t$ CLA isomers ( $t$ CLAs) and $t 10 c 12$ CLA concentrations were higher in both examined groups in comparison to the control group in MLD (Table 6). No difference in $c 9 t 11$ CLA concentration was observed among all groups in $M L D$. On the other hand, in $M B F$ the addition of SeY and SeVI to diets increased only $t$ CLAs concentration but decreased $c 9 t 11 \mathrm{CLA}$ content in comparison to the control group; however, in SeVI group this decrease was more pronounced. Moreover, SeY and SeVI diets decreased concentration of the sum of 


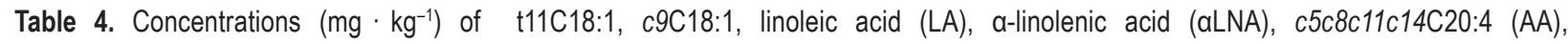
c7c10c13c16c19C22:5 (DPA), c4c7c10c13c16c19C22:6 (DHA) and sums of monounsaturated fatty acids (MUFA) ${ }^{4}$, polyunsaturated fatty acids (PUFA) $)^{5}, n-6$ PUFA ( $\left.\mathrm{n}-6\right)^{6}$ and $n$-3PUFA ( $\left.\mathrm{n}-3\right)^{7}$ in musculus longissimus dorsi (MLD) and musculus biceps fermoris (MBF) of lambs fed control and experimental diets

\begin{tabular}{|c|c|c|c|c|c|c|c|c|c|c|c|c|}
\hline Group ${ }^{1}$ & $\Delta 9_{\text {index }}{ }^{2}$ & t11C18:1 & c9C18:1 & MUFA & $\mathrm{LA}$ & aLNA & AA & DPA & $\mathrm{DHA}$ & PUFA & $n-6$ & $n-3$ \\
\hline \multicolumn{13}{|l|}{$\overline{M L D}$} \\
\hline control & 0.683 & $--^{3}$ & 3921 & 4832 & 138 & 80 & 167 & 66 & 35 & 550 & 333 & 205 \\
\hline $\mathrm{SeY}$ & $0.695^{*}$ & $18.7^{\star}$ & $6093^{*}$ & $6864^{*}$ & 154 & $111^{*}$ & 178 & 43 & $17^{*}$ & 549 & 348 & 191 \\
\hline SeVI & $0.657^{* \#}$ & $11.4^{* \#}$ & $3810^{\#}$ & $4381^{\#}$ & 146 & $61^{\#}$ & 175 & 41 & $11^{*}$ & 474 & 335 & $133^{* \#}$ \\
\hline SEM & 0.003 & 0.4 & 377 & 421 & 6 & 7 & 5 & 4 & 3 & 14 & 8 & 8 \\
\hline \multicolumn{13}{|l|}{ MBF } \\
\hline control & 0.671 & 11.0 & 2960 & 3250 & 145 & 47 & 135 & 33 & 24 & 413 & 287 & 125 \\
\hline $\mathrm{SeY}$ & $0.694^{*}$ & $26.0^{*}$ & $4574^{*}$ & $5104^{*}$ & $197^{b^{*}}$ & $73^{*}$ & $214^{* *}$ & 37 & 17 & $584^{*}$ & $424^{*}$ & 150 \\
\hline SeVl & $0.657^{\#}$ & $18.9^{* \#}$ & $2852^{\#}$ & $3192^{\#}$ & 178 & 53 & $202^{* *}$ & 37 & 14 & 525 & 397 & 125 \\
\hline SEM & 0.004 & 1.1 & 231 & 276 & 7 & 3 & 8 & 1 & 2 & 20 & 9 & 4 \\
\hline
\end{tabular}

${ }^{1}$ see Table $2 ;{ }^{2} \Delta 9_{\text {index }}-\Delta 9$-desaturase index $=c 9 \mathrm{C} 18: 1 /$ ( $\left.c 9 \mathrm{C} 18: 1+\mathrm{C} 18: 0\right) ;{ }^{3}$ below quantification limit $\left(3 \mathrm{x}\right.$ detection limit); ${ }^{4} \mathrm{MUFA}-$ sum of: $c 7 C 14: 1, c 9 C 14: 1, c 7 C 15: 1, c 9 C 16: 1, c 10 C 16: 1, c 9 C 17: 1, c 10 C 17: 1, c 6 C 18: 1, c 9 C 18: 1, t 11 \mathrm{C} 18: 1, c 12 \mathrm{C} 18: 1, c 11 \mathrm{C} 20: 1$ and $c 13 \mathrm{C} 22: 1$; ${ }^{5}$ PUFA - sum of $c 9 c 12 \mathrm{C} 16: 2, c 6 c 9 c 12 \mathrm{C} 16: 3$, $\Sigma \mathrm{CLA}$ (Table 6), $n$-3PUFA and $n$-6PUFA; ${ }^{6} \mathrm{n}-6$ - sum of $c 9 c 12 \mathrm{C} 18: 2, c 6 c 9 c 12 \mathrm{C} 18: 3, c 11 c 14 \mathrm{C} 20: 2$, $c 8 c 11 c 14 C 20: 3, A A, c 13 c 16 \mathrm{C} 22: 2$ and $c 7 c 10 c 13 c 16 C 22: 4 ;{ }^{7}$ n-3 - sum of $\alpha$ LNA, c11c14c17C20:3, c8c11c14c17C20:4, EPA, DPA and DHA; mean values in columns (for each muscle separately) with ${ }_{* * *}^{* *}$ are significantly different from control group at $P<0.05$ or $P<0.01$, respectively, and ${ }^{\#, \#}$ - from SeY group at $P<0.05$ or $P<0.01$, respectively

Table 5. Concentration sums of long-chain PUFA (LPUFA) $)^{1}$ and $n$-3LPUFA $(n-3 \mathrm{~L})^{2}$, and values of $n-6: n-3$ ratio, $\Delta 4$ - and $\Delta 5$-desaturase indexes $\left(\Delta 4_{\text {index }} \text { and } \Delta 5_{\text {index }}\right)^{3,4}$, fatty acid elongase index $\left(\mathrm{El}_{\text {index }}\right)^{5}$, and PUFA : SFA, PUFA : FA, LPUFA : FA, $n$-3L : SFA and $n-3 \mathrm{~L}$ : FA ratios in musculus longissimus dorsi (MLD) and musculus biceps fermoris (MBF) of lambs fed control and experimental diets

\begin{tabular}{|c|c|c|c|c|c|c|c|c|c|c|c|}
\hline Group ${ }^{2}$ & $\begin{array}{l}\text { LPUFA, } \\
\mathrm{mg} \cdot \mathrm{kg}^{-1}\end{array}$ & $\begin{array}{l}n-3 \mathrm{~L}, \\
\mathrm{mg} \cdot \mathrm{kg}^{-1}\end{array}$ & $n-6: n-3$ & $\Delta 4_{\text {index }}{ }^{3}$ & $\Delta 5_{\text {index }}{ }^{4}$ & $\mathrm{El}_{\text {index }}^{5}$ & PUFA : $S$ & PUFA : FA & LPUFA: FA & $n-3 \mathrm{~L}:$ SFA & $n-3 L: F A$ \\
\hline \multicolumn{12}{|l|}{$M L D$} \\
\hline control & 320 & 125 & 1.68 & 0.370 & 0.859 & 0.702 & 0.135 & 0.061 & 35.7 & 31.1 & 14.0 \\
\hline $\mathrm{SeY}$ & 274 & $-80^{*}$ & 2.02 & $0.289^{*}$ & $0.925^{*}$ & 0.692 & $0.096^{* *}$ & $0.045^{\star}$ & $22.2^{*}$ & $11.6^{* *}$ & $5.6^{*}$ \\
\hline SeVI & 261 & $-72^{*}$ & $2.71^{* \#}$ & $0.257^{\star}$ & $0.919^{*}$ & 0.685 & $0.131 \#$ & $0.062^{\#}$ & $33.7^{\#}$ & $16.3^{\star \star \#}$ & $7.8^{*}$ \\
\hline SEM & -10 & -5 & 0.09 & 0.020 & 0.008 & 0.021 & 0.007 & 0.003 & 1.2 & 1.1 & 0.5 \\
\hline \multicolumn{12}{|l|}{$M B F$} \\
\hline control & 220 & 78.0 & 2.30 & 0.378 & 0.957 & 0.618 & 0.115 & 0.057 & 30.5 & 21.8 & 10.8 \\
\hline $\mathrm{SeY}$ & $304^{*}$ & 77.5 & 2.89 & $0.298^{*}$ & 0.949 & 0.615 & 0.111 & 0.053 & 27.7 & $14.7^{*}$ & 7.1 \\
\hline SeVI & 290 & 71.5 & $3.18^{*}$ & $0.283^{*}$ & 0.923 & 0.641 & $0.154^{* \#}$ & $0.074^{\#}$ & $40.8^{* \#}$ & $20.9^{\#}$ & 10.0 \\
\hline SEM & 9 & 1.6 & 0.08 & 0.015 & 0.006 & 0.011 & 0.009 & 0.003 & 1.2 & 1.5 & 0.7 \\
\hline
\end{tabular}

${ }^{1}$ LPUFA - sum of: c11c14C20:2, c8c11c14C20:3, AA, c13c16C22:2, c7c10c13c16C22:4 and $n$-3L; ${ }^{2} n-3 \mathrm{~L}-$ sum of: $c 11 c 14 c 17 \mathrm{C} 20: 3$, c8c11c14c17C20:4, c5c8c11c14c17C20:5, DPA and DHA; ${ }^{2}$ see Table $2 ;{ }^{3} \Delta 4_{\text {index }}=$ DHA / (DHA + DPA); ${ }^{4} \Delta 5_{\text {index }}=A A /(A A+c 8 c 11 c 14 C 20: 3)$; ${ }^{5} \mathrm{El}_{\text {index }}=\mathrm{DPA} /(\mathrm{DPA}+\mathrm{c} 5 \mathrm{c} 8 \mathrm{c} 11 \mathrm{c} 14 \mathrm{c} 17 \mathrm{C} 20: 5)$; mean values in columns (for each muscle separately) with superscripts ${ }^{*, * *}$ are significantly different from control group at $P<0.05$ or $P<0.01$, respectively and with superscripts $\#$, from SeY group at $P<0.05$ or $P<0.01$, respectively

tc/ctCLAisomers (tc/ctCLAs) in MBF in comparison to the control group; no such effect was observed in $M L D$. The concentration sum of all assayed CLA isomers ( $\Sigma$ CLA) was higher $(P<0.05)$ in $M L D$ than $M B F$ of lambs fed control and experimental diets. The overall content of $\Sigma$ CLAs in $M L D$ was higher in $\mathrm{SeY}$ group in comparison to the control group but not in SeVI group. Higher $\Sigma$ CLA content in $M B F$ was measured in both experimental groups.

\section{Discussion}

No visual macroscopic lesions and visual toxic symptoms of diets containing $\mathrm{SeY}$ and SeVI (like respiratory distress syndrome, renal failure, vascular symptoms such as tachycardia, neurological features including tremors) were observed in lambs fed similar diets in the previous study (Jennifer et al., 2010). In fact, the SeY and SeVI diets 
Table 6. Concentrations $\left(\mathrm{mg} \cdot \mathrm{kg}^{-1}\right)$ of $t \mathrm{CLA}{ }^{1}, t 10 \mathrm{c} 12 \mathrm{CLA}, \mathrm{c} 9 \mathrm{t11CLA}$, tc/ctCLA ${ }^{2}$ and the sum of all assayed CLA isomers $(\Sigma C L A)^{3}$ in musculus longissimus dorsi (MLD) and musculus biceps fermoris (MBF) of lambs fed control and experimental diets

\begin{tabular}{|c|c|c|c|c|c|}
\hline Group ${ }^{4}$ & $t t C L A$ & $t 10 c 12 C L A$ & c9t11CLA & tc/ctCLA & $\Sigma \mathrm{CLA}^{5}$ \\
\hline \multicolumn{6}{|l|}{$M L D$} \\
\hline control & 29.6 & 3.5 & 35.8 & 39.3 & 84.6 \\
\hline $\mathrm{SeY}$ & $58.3^{*}$ & $12.4^{*}$ & 30.3 & 42.8 & $124.8^{*}$ \\
\hline SeVI & $50.8^{*}$ & $12.6^{*}$ & 28.0 & 40.6 & 104.8 \\
\hline SEM & 5.4 & 2.8 & 5.1 & 5.2 & 5.4 \\
\hline \multicolumn{6}{|l|}{ MBF } \\
\hline control & 4.7 & 4.1 & 19.3 & 23.3 & 32.1 \\
\hline $\mathrm{SeY}$ & $323.3^{* *}$ & 3.8 & $10.1^{*}$ & $13.9^{*}$ & $60.2^{*}$ \\
\hline SeVI & $24.4^{* *}$ & 2.7 & $6.1^{* \#}$ & $8.8^{*}$ & $55.9^{*}$ \\
\hline SEM & 2.7 & 0.6 & 1.0 & 1.4 & 3.2 \\
\hline \multicolumn{6}{|c|}{ 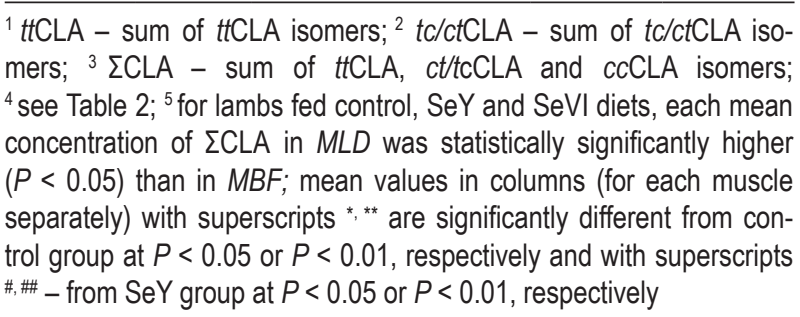 } \\
\hline
\end{tabular}

resulted in a relatively small increase $(P<0.05)$ in the concentration of Se in the liver $(65-70 \%)$, heart (48-50\%), blood (26-49\%), MLD (30-45\%) and MBF (28 - 36\%) in comparison to the control diet (Ruszczyńska et al., 2016). Moreover, recent reports showed that diets containing up to $2 \mathrm{mg}$ Se per $\mathrm{kg}$ of feed would not be toxic for animals (McDowell et al., 2005; Eun et al., 2013; Netto et al., 2014). However, a chronic dietary addition of inorganic Se-compounds (like SeVI or selenite) at rates of more than $5 \mathrm{mg} \mathrm{Se} \cdot \mathrm{kg}^{-1}$ can be hepatotoxic and teratogenic in animals and humans (Whanger, 2004; Navarro-Alarcon and Cabrera-Vique, 2008). In contrast to selenide, selenite and SeVI, Se coupled with methionine (Se-Met) is less reactive, and be-

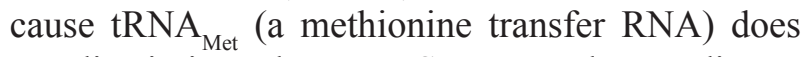
not discriminate between Se-Met and Met, dietary Se-Met is incorporated into body protein in place of Met (Weiss and Hogan, 2005; Navarro-Alarcon and Cabrera-Vique, 2008; Thiry et al., 2012).

Effects of SeY or SeVI on BWG and the profiles of SFA and MUFA in muscles. It was observed that the addition of SeVI to diet of increased the $\mathrm{BWG}_{35 \text { days }}$ of lambs in comparison to control and SeY groups (Table 2). Indeed, our recent study showed that the feeding SeVI diet reduced ruminal microbial fermentation rate (Miltko et al., 2016). This diet most effectively decreased the capacity of ruminal fermentation of carbohydrates into VFA (like acetic, propionic, butyric and valeric acids) and lipogenic enzymes in the lamb body (acetate is a precursor for lipogenesis). Moreover, the addition of SeVI most efficiently decreased formation of $\mathrm{CH}_{4}$ (a high-energy compound) and $\mathrm{CO}_{2}$ in the rumen (RozbickaWieczorek et al., 2016). $\mathrm{CH}_{4}$ is the high-energy compound and its elimination, as a waste product, causes the loss of $\sim 8 \%$ of the total digestible energy of the lamb diet (Wolin, 1979). So, the SeVI diet most effectively stimulates the $\mathrm{BWG}_{35 \text { days }}$ of lamb as the concentration of $\mathrm{CH}_{4}$ and $\mathrm{CO}_{2}$ in the rumen are the lowest. Furthermore, in the SeVI group the bacterial conversion of valine and leucine to $i s o$-butyric and iso-valeric acid was reduced as compared to the SeY group (Miltko et al., 2016). Therefore, the SeVI diet most effectively decreased the microbial fermentation rate and the degradation of amino acids derived from dietary proteins. So, dietary SeVI increases the efficiency of the diet concentrate utilization. As consequence, the addition of SeVI to diet resulted in the higher increase in BWG after 21 and 35 days in comparison to the control diet.

Similarly to the control lambs, in lambs fed SeY diet the concentrations of VFA (especially acetic acid) as well as $\mathrm{CO}_{2}$ and $\mathrm{CH}_{4}$ (waste products) in the rumen were increased in comparison to SeVI lambs (Rozbicka-Wieczorek et al., 2016). As a consequence, the lamb $\mathrm{BWG}_{35 \text { days }}$ observed for SeY group did not differ from the control group and was lower than for the SeVI group.

Recent studies revealed that the SeY diet increased the concentration of acetic acid in the ruminal fluids in comparison to control and SeVI diets (Miltko et al., 2016). As a consequence, the highest concentration of acetic acid in the ruminal fluid of lambs from the $\mathrm{SeY}$ group resulted in an increase in the biosynthesis yield of acetyl coenzyme A (acetyl-CoA) for biosynthesis of fatty acids in lamb tissues (Berg et al., 2002). Thus, the SeY diet most efficiently increased the concentrations of C14:0, C16:0, $\mathrm{C} 18: 0, \mathrm{~A}^{\mathrm{SFA}}, \mathrm{T}^{\mathrm{SFA}}$, MUFA and FA in $M L D$ and $M B F$ (Tables 3 and 4). Considering the above, it can be suggested that the addition of SeY most efficiently stimulated the yield of de novo biosynthesis and anabolism of FA in $M L D$ and $M B F$. In fact, the most efficient increase in concentrations of straight-chain and iso-VFA in ruminal fluids of lambs fed SeY diet (Miltko et al., 2016) suggest the greatest ruminal microbial fermentation rate (Wang et al., 2009). Indeed, a chemical form of dietary Se affects a biosynthesis yield of Se-complexes and Se-proteins in ruminal microbiota. Se-Met derived from dietary $\mathrm{SeY}$ is degraded to inorganic chemical forms of $\mathrm{Se}$ 
or re-incorporated into microbial proteins as Se-Met or Se-cysteine (Mainville et al., 2009; Czauderna et al., 2012b, 2015).

Feeding SeVI diet caused lower concentrations of C14:0, C16:0, C18:0, $\mathrm{A}^{\mathrm{SFA}}, \mathrm{T}^{\mathrm{SFA}}$, MUFA and FA in $M L D$ and $M B F$ in comparison to the SeY diet which did not differ from the control group. So, the current results are in agreement with the previous investigation in which the addition of SeVI to diet more efficiently decreased the concentrations of all straight-chain VFA in ruminal fluids than SeY (Miltko et al., 2016); dietary SeVI (the strong oxidant) reduced ruminal microbial fermentation rate and intakes of digestible energy and digestible organic matter. Indeed, recent studies (Navarro-Alarcon and CabreraVique, 2008) support the concept that Se prooxidative effects of inorganic Se-compounds (like SeVI or selenite) are due to the catalysis of hydrosulphide oxidation that results in decreasing the synthesis yield of lipogenic enzymes (e.g., acetyl-CoA carboxylase and fatty acid synthase) in animal tissues. Furthermore, our previous study (Miltko et al., 2016) showed that the lowest concentration of acetic acid in the ruminal fluid collected from lambs fed SeVI diet resulted in decreasing the biosynthesis yield of acetyl-CoA for synthesis of lipids in lamb tissues. In fact, acetic acid is the major source of acetyl-CoA for biosynthesis of lipids; acetic acid is oxidized almost throughout the whole body to generate adenosine triphosphate (ATP), whereas butyric acid is oxidized in many tissues for energy production (Berg et al., 2002). Therefore, we argued that the lowest concentration of VFA in ruminal fluids of lambs fed the SeVI diet is responsible for the smallest concentration of FA in $M L D$ and $M B F$ (Rozbicka-Wieczorek et al., 2016). So, current study documented that the feeding lambs SeVI in contrast to SeY did not increase the concentration of FA in $M L D$ and $M B F$ and so not differ from the control group.

Effects of SeY or SeVI on the concentrations of PUFA in muscles. In lambs fed $\mathrm{SeY}$ and SeVI diets the concentration of $t 11 \mathrm{C} 18: 1$ in $M L D$ and $M B F$ was increased in comparison to the control group. Interestingly, the concentration of $t 11 \mathrm{C} 18: 1$ in $M L D$ of lambs from the control group was undetectable (i.e. below the quantification limit). Therefore, it can be suggested that the addition of CA to the diet with RO and FO (the control diet) modify ruminal microbiota and hence FA metabolism, especially bacterial formation of $t 11 \mathrm{C} 18: 1$ in the rumen (i.e. ruminal isomerization and biohydrogenation) (Morán et al., 2012, 2013). In fact,feeding such composed basal diet most efficiently stimulated the formation of c9t11CLA (product of bacterial isomerization) in $M B F$
(Table 6), while reduced the biohydrogenation yield of $c 9 t 11$ CLA to $t 11 \mathrm{C} 18: 1$ (Table 4) and the terminal biohydrogenation of $t 11 \mathrm{C} 18: 1$ to $\mathrm{C} 18: 0$ in the rumen (Table 3). In contrast, feeding lambs with SeVI and especially $\mathrm{SeY}$ diets stimulated the ruminal bacterial isomerization of UFA to $t t$ CLA isomers ( $t t C L A$ ) in comparison to the control diet. As a consequence, in lambs fed SeY and SeVI diets the content of $t t$ CLA in both $M L D$ and $M B F$ was increased.

Moreover, in lambs fed SeVI or especially SeY diet the effects of the control diet (i.e. isomerization and biohydrogenation) were diminished. Thus, the concentration of $t 11 \mathrm{C} 18: 1$ was greater in $M L D$ and $M B F$ of lambs fed diet including SeVI or especially $\mathrm{SeY}$ than the control diet (Table 4). Simultaneously, the concentration of c9t11CLA was lower in $M B F$ of lambs fed SeY and SeVI diets than the control diet. Moreover, the SeVI diet more efficiently reduced the concentration of $c 9 t 11$ CLA in $M B F$ than the SeY diet. So, we argued that the SeVI diet reduced the bacterial isomerization to c9t11CLA and the biohydrogenation to $11 \mathrm{C} 18: 1$ in the rumen compared to the diet containing SeY.

In lambs fed $\mathrm{SeY}$ and $\mathrm{SeVI}$ diets the lower values of $\triangle 4_{\text {index }}$ in $M L D$ and $M B F$ were measured in comparison to the control group; as a consequence, the lower concentrations of DHA were observed in $M L D$ of lambs fed SeY and SeVI diets than the control diet (Table 4). So, our result documented that the capacity of $\Delta 4$-desaturation (i.e. $\Delta 4_{\text {index }}$ ) limited the biosynthesis yield of DHA in particular in $M L D$ . Considering the above results, it can be suggested that $\Delta 5$-desaturation and fatty acid elongase revealed negligible impact on the biosynthesis yield of LPUFA (especially DHA).

In $M L D$ of lambs fed SeY diet lower PUFA : SFA, PUFA:FA, LPUFA:FA, n-3L:SFAratios were observed in comparison to control and SeVI groups, and n-3L: FA ratio in comparison to the control group. In contrast, in $M B F$ of lambs fed SeVI diet PUFA: SFA, LPUFA: FA ratios were increased in comparison to control and SeY groups, and PUFA : FA ratio in comparison to with $\mathrm{SeY}$ group. In fact, in lambs feeding the $\mathrm{SeY}$ diet the concentrations of SFA in $M B F$, and FA in $M L D$ and $M B F$ were increased when compared to the SeVI and control diets. Furthermore, feeding SeY diet more effectively increased the concentrations of $\mathrm{A}^{\mathrm{SFA}}$ (especially pro-atherogenic C14:0; Morán et al., 2013) and T $\mathrm{T}^{\mathrm{SFA}}$ in both $M L D$ and $M B F$ than the control and SeVI diets; also it elevated the values of ${ }_{\text {index }} \mathrm{A}^{\mathrm{SFA}}$ and $\mathrm{A}^{\mathrm{SFA}}$ : FA ratio in $M L D$ in comparison to $\mathrm{SeVI}$ and control diets. Thus, the SeY addition to the lamb diet should not be promoted from dietary point of view. Such 
addition enriches muscle tissues in SFA exerting proatherogenic and pro-thrombotic properties after in excess consumption.

\section{Conclusions}

Addition of inorganic Se (sodium selenate) or organic Se (selenized yeast) into lamb diet based on rapeseed oil, fish oil and carnosic acid differently modifies body weight gains as well as fatty acids profile in different types of muscles: musculus longissimus dorsi and musculus biceps femoris. So, the obtained data constitute new information for nutritionists who conduct researches on the nutritional quality of feed for ruminants and the dietary properties of meat for humans. However, further researches are needed to better understand the role of different chemical forms of selenium in ruminant feeding.

\section{Acknowledgements}

This study was partially supported by the National Science Centre (NCN): Grant No. 2013/ 09/B/NZ9/00291. We would like to thank Mr. J. Rutkowski (m.v.Sc) for his help and professional veterinary expertise.

\section{References}

Berg J.M., Tymoczko J.L., Stryer L., 2002. Biochemistry. $5^{\text {th }}$ Edition. W.H. Freeman (Editor). Available from: http://www.ncbi.nlm nih.gov/books/NBK22381/

Buccioni A., Decandia M., Minieri S., Molle G., Cabiddu A., 2012. Lipid metabolism in rumen: New insights on the lipolysis and biohydrogenation with an emphasis on the role of endogenous plant factors. Anim. Feed Sci. Tech. 174, 1-25

Czauderna M., Kowalczyk J., Marounek M., 2012a. Dietary linseed oil and selenate affect the concentration of fatty acids in selected tissues of sheep. Czech J. Anim. Sci. 57, 389-401

Czauderna M., Kowalczyk J., Niedźwiedzka K.M., Leng L., Cobanova K., 2009. Dietary selenized yeast and CLA isomer mixture affect fatty- and amino acid concentrations in the femoral muscles and liver of rats. J. Anim. Feed Sci. 18, 348-361

Czauderna M., Kowalczyk J., Wallace R.J., 2012b. Selenite and selenate affected the fatty acid profile in in vitro incubated ovine ruminal fluid containing linoleic acid. J. Anim. Feed Sci. 21, 477-492

Czauderna M., Rozbicka-Wieczorek A.J., Więsyk E., KrajewskaBienias K.A., 2015. Seleno-methionine decreases biohydrogenation of $\mathrm{C} 18$ unsaturated fatty acids in ovine ruminal fluid incubated in vitro with a-linolenic acid. Eur. J. Lipid Sci. Tech. $117,820-828$

Demirel G., Wachira A.M., Sinclair L.A., Wilkinson R.G., Wood J.D., Enser M., 2004. Effects of dietary n-3 polyunsaturated fatty acids, breed and dietary vitamin $\mathrm{E}$ on the fatty acids of lamb muscle, liver and adipose tissue. Brit. J. Nutr. 91, $551-565$
Eun J.-S., Davis T.Z., Vera J.M., Miller D.N., Panter K.E., ZoBell D.R., 2013. Addition of high concentration of inorganic selenium in orchardgrass (Dactylis glomerata L.) hay diet does not interfere with microbial fermentation in mixed ruminal microorganisms in continuous cultures. Prof. Anim. Sci. 29, 39-45

Hernández-Hernández E., Ponce-Alquicira E., Jaramillo-Flores M.E., Guerrero Legarreta I., 2009. Antioxidant effect rosemary (Rosmarinus officinalis L.) and oregano (Origanum vulgare L.) extracts on TBARS and colour of model raw pork batters. Meat Sci. 81, 410-417

Jennifer K., MacFarquhar R.N., Broussard D.L. et al., 2010. Acute selenium toxicity associated with a dietary supplement. Arch. Intern. Med. 170, 256-261

Jordan M.J., Lax V., Rota M.C., Loran S., Sotomayor J.A., 2013. Effect of the phenological stage on the chemical composition, and antimicrobial and antioxidant properties of Rosmarinus officinalis $\mathrm{L}$ essential oil and its polyphenolic extract. Ind. Crop. Prod. 48, 144-152

Juniper D.T., Phipps R.H., Ramos-Morales E., Bertin G., 2008. Effect of dietary supplementation with selenium-enriched yeast or sodium selenite on selenium tissue distribution and meat quality in beef cattle. J. Anim. Sci. 86, 3100-3109

Kišidayová S., Mihaliková K., Siroka P., Čobanová K., Váradyová Z., 2014. Effects of inorganic and organic selenium on the fatty acid composition of rumen contents of sheep and the rumen bacteria and ciliated protozoa. Anim. Feed Sci. Tech. 193, 51-57

Krajewska K.A., Rozbicka-Wieczorek A.J., Kowalczyk J., Czauderna M., 2012. Dietary linseed oil and selenate affect the concentration of fatty acids and selenium in the spleen, pancreas, and kidneys of lambs. J. Anim. Feed Sci. 21, 285-301

Mainville A.M., Odongo N.E., Bettger W.J., McBride B.W., Osborne V.R., 2009. Selenium uptake by ruminal microorganisms from organic and inorganic sources in dairy cows. Can. J. Anim. Sci. 89, 105-110

McDowell L.R., Davis P.A., Cristaldi L.A., Wilkinson N.S., Buergelt C.D., Van Alstyne R., 2005. Toxicity of selenium: fear or precaution? Feedstuffs 77, No. 22, 12-13

Miltko R., Rozbicka-Wieczorek A.J., Więsyk E., Czauderna M., 2016. The influence of different chemical forms of selenium added to the diet including carnosic acid, fish oil and rapeseed oil on the formation of volatile fatty acids and methane in rumen and fatty acid profiles in the rumen content and muscles of lambs. Acta Vet. - Beograd (in press)

Morán L., Andrés S., Bodas R., Benavides J., Prieto N., Pérez V., Giráldez F.J., 2012. Antioxidants included in the diet of fattening lambs: Effects on immune response, stress, welfare and distal gut microbiota. Anim. Feed Sci. Tech. 173, 177-185

Morán L., Giráldez F.J., Panseri S., Aldai N., Jordán M.J., Chiesa L.M., Andrés S., 2013. Effect of dietary carnosic acid on the fatty acid profile and flavour stability of meat from fattening lambs. Food Chem. 138, 2407-2414

Navarro-Alarcon M., Cabrera-Vique C., 2008. Selenium in food and the human body: A review. Sci. Total Environ. 400, 115-141

Netto A.S., Zanetti M.A., Correa L.B., Del Claro G.R., Salles M.S.V., Vilela F.G., 2014. Effects of dietary selenium, sulphur and copper levels on selenium concentration in the serum and liver of lamb. Asian Austral. J. Anim. Sci. 27, 1082-1087

Niedźwiedzka M.K., Kowalczyk J., Czauderna M., 2008. Influence of selenate and linseed oil on fatty-acid and amino-acid profiles in the liver, muscles, fat tissues and blood plasma of sheep. J. Anim. Feed Sci. 17, 328-343

Ohgushi-Imamura T., Orden E.A., Fujihara T., 2014. Utilization of microbial selenium collected from the rumen of sheep. J. Anim. Feed Sci. 23, 124-130 
Rozbicka-Wieczorek A.J., Więsyk E., Brzóska F., Śliwiński B., Kowalczyk J., Czauderna M., 2014. Efficiency of fatty acid accumulation into breast muscles of chickens fed diets with lycopene, fish oil and different chemical selenium forms. Afr. J. Biotechnol. 13, 1604-1613

Rozbicka-Wieczorek A.J., Wiesyk E., Krajewska-Bienias K.A., Wereszka K., Czauderna M., 2016. Supplementation effects of selenocompounds, carnosic acid and fish oil on concentrations of fatty acids, tocopherols, cholesterol and amino acids in the liver of lambs. Turk. J. Vet. Anim. Sci. DOI: 10.3906/vet-1509-12

Ruszczyńska A., Rutkowska D., Bulska E., Czauderna M., 2016. Effects of carnosic acid, fish oil and seleno-compounds on the level of selenium and fatty acids in lamb muscles. In: Proceedings of XLV Scientific Session of Group of Animal Nutrition KNZiA PAN Olsztyn (Poland), pp. 90-91

Thiry C., Ruttens A., De Temmerman L., Schneider Y.-J., Pussemier L., 2012. Current knowledge in species-related bioavailability of selenium in food. Food Chem. 130, 767-784

Traulsen H., Steinbrenner H., Buchczyk D.P., Klotz L.-O., Sies H., 2004. Selenoprotein P protects low-density lipoprotein against oxidation. Free Radical Res. 38, 123-128
Wang C., Liu Q., Yang W.Z., Dong Q., Yang X.M., He D.C., Zhang P., Dong K.H., Huang Y.X., 2009. Effects of selenium yeast on rumen fermentation, lactation performance and feed digestibilities in lactating dairy cows. Livest. Sci. 126, 239-244

Wasowska I., Maia M.R.G., Niedźwiedzka K.M., Czauderna M., Ramalho Ribeiro J.M.C., Devillard E., Shingfield K.J., Wallace R.J., 2006. Influence of fish oil on ruminal biohydrogenation of $\mathrm{C} 18$ unsaturated fatty acids. Brit. J. Nutr. 95, 1199-1211

Weiss W.P., Hogan J.S., 2005. Effect of selenium source on selenium status, neutrophil function, and response to intramammary endotoxin challenge of dairy cows. J. Dairy Sci. 88, 4366-4374

Whanger P.D., 2004. Selenium and its relationship to cancer: an update. Brit. J. Nutr. 91, 11-28

Wolin M.J., 1979. The Rumen fermentation: a model for microbial interactions in anaerobic ecosystems. Adv. Microb. Ecol. 3, 49-77 